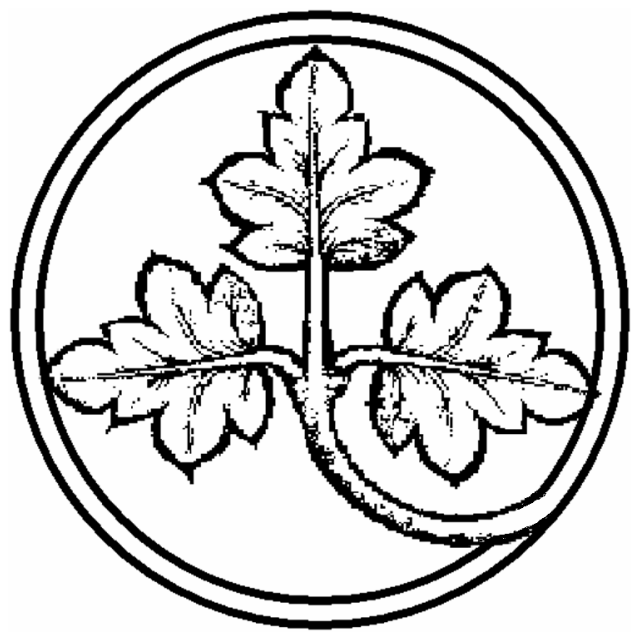

\author{
Preprints of the \\ Max Planck Institute \\ for Research on Collective Goods \\ Bonn \\ 2005/19
}

Market Discipline, Information Processing, and Corporate Governance

Martin Hellwig 


\section{Market Discipline, Information Processing, and Corporate Governance}

Martin Hellwig

October 2005 


\title{
Market Discipline, Information Processing, and Corporate Governance ${ }^{1}$
}

\author{
Martin Hellwig
}

\section{Rhetoric, Semantics, and Reality of "Market Discipline"}

This paper discusses the rhetoric, the semantics, and the reality of "market discipline" in the nineties. "Market Discipline” has been one of the miracle words of the last decade. In 1998, lack of market discipline was cited as a major source of the Korean crisis. Institutional changes designed to strengthen market forces and market discipline were a precondition of IMF help. Earlier in the nineties, one could hear that the resumption of capital flows to Mexico and other Latin American countries was closely tied to the use of market-related financing instruments, direct investments and portfolio investments, which were protected by "market discipline" - unlike the bank loans of the seventies, which had to be repeatedly renegotiated in the international debt crisis of the eighties. Questions about the effectiveness of "market discipline”, say for the protection, following the Mexican Revolution of 1911, of direct investments and portfolio investments in the eighteen-nineties would typically be dismissed as being politically incorrect.

The notion of "market discipline” also figures prominently in discussions about bank failures and banking crises and about the prudential regulation and supervision of banks. Based on Calomiris and Kahn (1991), Calomiris (1998, 1999) has called for a system of banking regulation which exploits markets (in this case, markets for subordinated debt) and the discipline that they impose to provide regulators information about where to intervene and where not and to provide incentives for bankers to behave well. The Calomiris position has not been adopted by the regulatory community, but even so, the Basel Committee on Banking Supervision (2004) is listing market discipline as the "third pillar" of risk control in banking, after capital requirements and the supervisory review process. These recommendations are to some extent motivated by the notion that the S\&L crisis of the eighties in the United States was due to a "lack of market discipline”,

1 Paper presented at the symposium on "Changes of Governance in Europe, Japan, and the US: Corporations, State, Markets, and Intermediaries”, organized by the Max Planck Institute for Foreign Private Law and Private International Law and the Japanese-German Center Berlin, September 9 - 11, 2004. I am grateful to Stefan Bechtold, Christoph Engel, and Isabel Schnabel for helpful comments and to the Deutsche Forschungsgemeinschaft for research support through Sonderforschungsbereich 504 and SonderforschungsbereichTransregio 15. 
as deposit insurance eliminated all incentives for depositors to monitor the institutions where they were depositing their savings.

References to "market discipline” should be seen as part of a wider debate on corporate finance and corporate governance. Elsewhere (Hellwig 2000), I have referred to this debate as the "ongoing repertory play 'banks versus markets'”, with some scepticism as to whether this is really the right play to be performing. In previous times, performances of this repertory play had enacted the myth that long-term implicit relations of nonfinancial institutions with banks were responsible for the perceived superiority of the German or the Japanese economy relative to the U.K. or the U.S. economy as these long-term relations enabled the German or Japanese financial systems to mobilize funds for large-scale, long-term investments (Gerschenkron 1962, Mayer 1988, Hoshi et al. 1990, 1991). In contrast, more recent performances have stressed the ability of markets - in a suitable legal and political environment - to provide finance to people who are complete outsiders to the system, thereby preventing the kind of sclerosis that sets in when routes to the top of the social hierarchy are strictly controlled by those who already are at the top (LaPorta et al. 1997, Rajan and Zingales 2003a, 2003b). Given the downturn of Japanese banks since the early nineties and the spectacular performance of worldwide stock markets in the second half of the nineties, ascendance in these debates has moved from the "pro-bank" to the "pro-market" exponents. However, the analytical basis for either assessment is unclear (see, e.g., the comments of Allen (2003) and Hellwig (2003) on Rajan and Zingales (2003b).

In this context, developments since 2000 should make us pause. Discoveries of fraud in companies like Enron, Worldcom, etc. raise questions about the reality of "market discipline”. Even where there was no wrongdoing, the ready availability of funds in the late nineties to any company with a "dotcom" in its name suggests that, at least at this time, markets did not impose much discipline. Cash was generously delivered and generously burnt. The subsequent burst of the bubble provides some indication of overvaluation. It also seems clear that there has been excessive real investment, e.g., in fibre glass transmission facilities in telecommunications. In current performances of the repertory play "banks versus markets", these developments are sometimes treated as unfortunate accidents due to the misdeeds of particular persons, soon to be eliminated through the enactment of appropriate new rules (Rajan and Zingales 2003b). I am not convinced of this assessment. One must be concerned about the possibility that the misreporting and fraud, the development of the bubble and its burst, as well as the long reluctance that the Administration and Congress in the Unites States have shown against corrective measures, may be a reflection of systematic problems which must be encompassed by any serious debate on finance and governance.

Any assessment of "market discipline" is impeded by the fact that the meaning of the term is unclear. Journalists nowadays use it with reference to day-to-day stock market valuations of firms and the interpretation of these valuations as a measure of corporate performance. However, for such market assessments to have a disciplinary effect, there must be a mechanism by which share prices feed into managerial incentives. In the eighties, the literature on the market for corporate control (e.g., Jensen and Ruback 1983) suggested that the takeover mechanism fulfils this 
role (though day-to-day stock market valuations play hardly a role in that context). The more recent literature on corporate governance (Shleifer and Vishny 1997, La Porta et al. 1997, 1998) still lists the legal environment facilitating hostile takeovers as one of the preconditions for a well-functioning "market-oriented" financial system, but given the developments of the nineties, emphasis on the takeover mechanism has been replaced by considerations of explicit managerial incentives. Perhaps the role of "shareholder value" rhetoric as a focus of boardroom conversation and boardroom rivalries should also be considered. How else could one explain that "shareholder value" standards have come into prominence even where shareholder powers were reduced or at least not increased?

In the context of banking and banking regulation, "market discipline" is used in yet another sense. In Calomiris and Kahn (1991) or Diamond and Rajan (2001) - and in the various critical assessments of the S\&L as well as other financial crises (Calomiris and Gorton 1991) - the banker is subjected to discipline by the requirement to repay deposits "on demand". The combination of the "on demand" clause and the sequential-service provision in the demand deposit contract provides depositors with an incentive to monitor the banker. If they don't like what they see, they can ask for their money back, with some chance that, if matters are really bad, they may be first in line at the bank. Here the disciplining mechanism is provided by an explicit contractual arrangement, though no market is involved. In Calomiris (1997), in contrast, the proposal is for bankers to have relatively short-term subordinated debt outstanding, which is traded in organized markets, so the market price of this debt indicates the market's assessment of the bank's solvency. As for the question of discipline, the premium over the market rate of interest which the market requires in order to be willing to hold the bank's debt is supposed to serve as a signal triggering supervisory intervention. In extreme cases, the unwillingness of the market to roll over the bank's subordinated debt when it comes due would force the bank out of business, either because it fails to meet the regulatory requirement of $\mathrm{x} \%$ subordinated debt or because the lack of the money itself creates an outright liquidity problem. In this proposal, there is an involvement of the market but, as in the corporate governance context, the disciplinary mechanism is not entirely clear. To a large extent, discipline is brought about by regulatory intervention on the basis of market signals rather than an intervention by market participants.

These observations suggest that perhaps the eminence of the term "market discipline" is based less on the analytical rigour of the concept(s) than on the emotional appeal of any reference to the strength of "markets". The emotional appeal is particularly strong in the United States, where "the market" serves as a dream factory second only to Hollywood, and where financial institutions as well as the media that thrive on "the market" seem to be in a position to determine the rules of public rhetoric. ${ }^{2}$ Rhetorically, "the market" tends to be identified with "the market system", which makes it difficult to express scepticism about the wonders that are to be expected from "market discipline”. For economists, the difficulty is particularly great because the notion

2 One sometimes wonders to what extent the "Washington consensus", by which such public discussion feeds into policy measures of the United States and of the International Monetary Fund, may not be reflecting the particular interests of these institutions; see Stiglitz (2002). 
that markets function well is at the core of economic theory, and we all know about the wonders that can be expected if the law of supply and demand is allowed to work without extraneous intervention.

However, we should appreciate that discussions of "market discipline" have little to do with "the market system" or even the simple notion of a "market" as it is analysed in economic theory. Economic theory looks at markets in the abstract, focussing on their implications for the allocation of resources, without saying anything - at least in general discussions - on the institutions that serve to implement these allocations. To the extent that we refer to this issue at all, we talk about a fictitious Walrasian auctioneer who sets prices so as to equate supplies and demands. We don't talk about this person's information, about his incentives, or even his wages - after all, he is just a fiction.

We do tell our students that, in real life, stock markets are the ones which most resemble the markets in our models, but we do not go on to make the policy recommendation that all markets should be organized like stock markets. When we see automobile markets characterized by close relations between producers and dealers, which enable consumers to identify a dealer with a certain brand, we do not complain about the lack of anonymity and the scope for corruption that are provided by such personalized car provision. Instead we see such vertical relations and the use of brand names as devices to handle moral hazard in relations between the producer and the distributor and to reduce the impact of information asymmetry about quality, solving problems which the Walrasian market model has not even addressed. Standard banking theory suggests a similar role for banks acting to facilitate economic transactions in the face of problems which, in the theoretical models, are hidden underneath the fictitious auctioneer (Hellwig 1998).

Thus, discussions of "market discipline" should be freed from references - explicitly or emotionally - to "the market system". In all of the instances given, "market discipline” is presented as a device to affect the behaviour of a corporate manager or a banker so as to reduce the agency costs associated with external financing of this person's operations. This has little to do with the law of supply and demand and a lot to do with the institutional framework which implements "market allocations", presumably in a way which reduces the impact of moral hazard and asymmetric information to ensure that the provision of external finance is reasonably viable. In terms of the automobile example, this is like the question of what combination of brand reputation and warranty provision is appropriate or what exclusionary clauses should be stipulated in the dealership contract.

Given the need to descend from the lofty heights of economic-systems rhetoric to the nitty-gritty of information and incentive problems, it is a bit disconcerting to see that the term "market discipline” covers so many different examples. It is also disconcerting that the term is used in a wholesale fashion without much concern for what the alternatives are in any one instance. In the following, I will attempt to bring some structure into the discussion, on both counts. I will begin with a discussion of what financial "markets" actually do and in what sense one can speak of "markets” as performing such functions differently from other institutions. In particular, I will 
discuss the specifics of information processing in different institutions and different governance structures. Finally, I will return to a discussion of "market discipline” and corporate governance.

\section{What Do Financial "Markets" Do? What Do They Do Differently?}

At a first glance, the answer to the question of what financial "markets" do is rather obvious: They provide finance to households and firms that need extra funds, relying on the surpluses of other units of the economy. In so doing, they have an influence on what kinds of expenditures are undertaken, in particular, what investment projects are selected, which in turn is a major determinant of the economy's return prospects and the economy's risks.

In cases where the investment horizons of final investors fall short of the length of life of an investment project, secondary financial "markets" provide liquidity, enabling the initial investor to sell when he wants to, even when the project is still going on. In such cases, the later returns of the investment project benefit the initial investor not because he is around to reap them, but because the prospect of these returns determines the price at which he can sell.

On a second look, however, one appreciates that the preceding account characterizes the functions of the financial system as a whole rather than anything specific about financial "markets". In a standard account of a bank-dominated financial system, we see banks collecting funds from households and firms with surpluses and using these funds to provide finance to households and firms that need them, thereby affecting what investment projects are selected and what return prospects and risks the economy is facing. To the extent that these banks engage in maturity transformation, they also provide liquidity, e.g., as the "on demand" clause enables each depositor to reap his returns whenever he wants to. At this superficial level then, there is no difference between the functions of a system of financial "markets" and the functions of a banking system.

In terms of the mechanics of the system, two major differences between a system based on "markets" and a system based on banks jump to the eye: First, on the financing side, "market" finance involves multiple financiers and tends to be more anonymous, with less of an ongoing relationship and less scope for "cronyism", than bank finance. Second, in terms of the relation between final users and final providers of funds, "market" finance tends to involve more direct finance, i.e., claims that are issued by the final user of funds and that directly expose the final provider of funds to the specific risks associated with the final user. For "market" finance, a paradigmatic example would be the initial public offering of common stock of a firm to final investors, for bank finance the use of customer deposits to provide bank loans to a firm in the context of an exclusive "main bank" relation.

However, there are many hybrids: Banks controlling access to the stock market in pre-1914 Germany and selling their customers the shares of firms with whom they had a main bank relation would be an instance of banks using their dominance over the financial system to influence an operation that would ordinarily be associated with "market" finance. The provision of bank 
loans to large corporations in Germany in the nineteen-eighties did not involve organized exchanges, yet it was by all accounts characterized by an absence of relationship effects and a high degree of competitiveness (Edwards and Fischer 1994). (The same can be said about Switzerland during these years.) The existence of such hybrids indicates that one must go beyond a wholesale observation of whether or not a financing operation involves organized exchanges and whether or not final providers of funds are left to bear specific risks, and instead look at the details of the interactions between the different units that are involved, final users of funds, final providers of funds, and financial institutions, from banks to stock brokers and analysts.

At this point, the discussion must turn to matters of information, incentives, and governance. As is well known, the financing relation is fraught with information and incentive problems because, in return for his money, the financier receives no more than a piece of paper with an I.O.U., the value of which is hard to assess and is indeed endogenous because it depends on the issuer's behaviour. If the issuer steals the money or mismanages it, the financier's claim is worth nothing; the same is true if the issuer is honest, but his undertaking is doomed to fail. For finance to be viable, the parties involved must find ways to reduce the impact of the information and incentive problems which thereby arise. The task is made difficult by the fact that the mere provision of external finance tends to generate moral hazard and adverse selection because (i) the mere existence of the financier's claim is likely to distort the issuer's incentives against all modes of behaviour that benefit the financier at a cost to himself, and (ii) the mere availability of finance is likely to attract "entrepreneurs" who know that they don't have much of a chance but may as well try it anyway - at somebody else’s expense.

To deal with these problems, financiers need information and control. Information should improve the selection of projects funded; it should also provide a base for monitoring whether the financing contract is being adhered to. Most importantly, information provides a base for using whatever scope for control the financier has been given. Control enables the financier to reduce moral hazard on the side of the borrower; however, control by the financier may be limited by the borrower's comparative advantage in running the venture and by the borrower's worry about moral hazard in the form of the financier's using his powers of control to expropriate him.

The use of information and control to support a financing relation depends on the provisions of the contract(s) and on the incentives of the different parties as the contract is being carried out. Incentives of the different parties depend in important ways on how many financiers there are; this is one point where the difference between "market” finance and bank finance matters. Two effects seem to be important: First, there is a public-goods effect by which the efforts of one financier at gathering information and exerting control over the management of the venture that is being funded benefit not just this financier, but all the other financiers as well. When there are multiple financiers, this public-goods effect gives rise to a free-rider problem because, at least in the absence of counteracting devices, each financier will tend to neglect the benefits that his effort brings for the other financiers. Relative to the efficient amount, there is then likely to be an undersupply of effort for information gathering and exertion of control. The free-rider problem is 
a major focus of discussion in the literature on corporate takeovers as an incentive mechanism supporting the viability of stock market finance (Manne 1968, Grossman and Hart 1980).

Second, any one financier's effort at gathering information and exerting control may impose negative externalities on the other financiers, serving redistributive rather than allocative purposes. This is the case, e.g., if the information collected by the bank depositor in a CalomirisKahn type of model and the liquidation induced by his withdrawal of funds have no effects on the total funds available to depositors ${ }^{3}$ and serve only to ensure that the informed depositor is the first to run so that he gets his money back and the others must do with whatever assets the bank has left. A similar redistributive externality is at work in models of costly information collection for the purpose of speculation in organized markets. Thus, in the standard models of Grossman and Stiglitz (1980) or Verrecchia (1982), with exogenously given asset supplies and asset returns, the speculative use of information advantages comes at the expense of other market participants, in particular those who have "real" reasons for wanting to trade and rely on secondary markets for liquidity. In the literature on market microstructure, this consideration provides one of the many arguments against the admission of insider trading (see, e.g., Dennert 1991).

Whereas the free-rider problem suggests that a multiplicity of financiers gives rise to an underinvestment in effort for information gathering and control, the redistributive externality considered in the preceding paragraph suggests the opposite. To the extent that information and control yield individual benefits at the expense of other participants and to the extent that effort choices neglect the negative externalities on other participants, private incentives for investing effort in information gathering and the exertion of control will tend to be excessive.

Having both the free-rider problem as a reason for underinvestment and the redistributive externality as a reason for overinvestment in information and control, one is tempted to conclude that there must be some number of outside financiers so that the two effects just cancel out and one actually gets an efficient level of investment in information and control. Efficiency here would have to be understood in a suitable n-th best sense, as referring to that level of investment which is called for from an optimal incentive-contracting perspective ex ante. By this interpretation, the number of financiers would have to be determined as part of the overall contract ex ante, with a view to its subsequent incentive implications.

The notion that the number of financiers should be determined ex ante with a view to its subsequent incentive implications is developed in Calomiris and Kahn (1991). However, they are less concerned with the redistributive externality ${ }^{4}$ than with the possibility that the information col-

3 Calomiris and Kahn (1991) assume that the bank's liquidation through a run prevents worse outcomes, and actually enhances the assets that are available to depositors. However, with multiple depositors, the incentive mechanism they describe does not depend on this assumption. Indeed, the redistributive externality described here has the interesting implication that the threat of premature liquidation under deposit finance may be credible and may therefore provide proper ex ante incentives, even though ex post it is (collectively) inefficient to carry this threat out.

4 Indeed, for the case of multiple depositors, the payoff matrix that they present is incomplete, which makes them miss the observation that the withdrawal game generated by their model exhibits the same multiplicity 
lected by multiple financiers, each receiving an independent signal, may, on aggregate, be better than whatever information a single financier could obtain. The very same notion underlies the view that stock market finance involves many people collecting information, with information aggregation through market prices providing a better base for decision making than would be available to any one investor. ${ }^{5}$ An example is provided by Allen (1993), who suggests that stock prices based on aggregate information provide better guidance for the allocation of investment funds than would be available on the basis of individual information.

The view that there are benefits to having multiple sources of information stands in marked contrast to the alternative view that information generation involves scale economies in that the duplicate generation of the same piece of information is wasteful. The Calomiris-Kahn model of deposit finance of banks and the theory of information aggregation through asset prices, which underlies the assessment of Allen (1993), are based on the assumption that additional pieces of information are not simply duplicating the first one, but are providing new signals in the sense that different information sources involve stochastically independent errors. We should recall, however, that the duplication-of-information view of multiple sources of information plays an important role in the theory of financial intermediation. Since Diamond (1984), much of the literature on financial intermediation has associated banking with the "delegated monitoring" of loan clients, the idea being that it suffices for the monitoring costs to be spent once, by one monitoring agent, and that duplicate monitoring would involve costs without providing more information. Given this view of duplicate monitoring, much of the literature on financial intermediation has been concerned with the agency costs that arise when the task of monitoring loan clients is "delegated" to an intermediary who collects funds from depositors and uses them to provide loans, while monitoring the loan clients. I will return to this question below, when I contrast the role of banks serving as financial intermediaries à la Diamond (1984) and the role of stock market institutions (brokers, analysts, accountants, investment bankers) providing information to shareholders.

The number of external financiers for a given user of funds also affects the strategic interdependence between the contracting parties. One factor may simply be negotiation costs and transactions costs. When the number of financiers is large, such costs may eliminate any scope for renegotiating the initial contract. Whereas in the international debt crisis of the eighties, the sovereign debts that had been incurred in the late seventies were renegotiated throughout the eighties with a consortium of a few hundred banks, in the international debt crisis of the thirties, the various sovereign bond issues of previous decades were not renegotiated and simply went into default. ${ }^{6}$ From a theoretical perspective, inability to renegotiate has advantages and disadvantages: The advantage is that threats of bankruptcy are more credible - and can have beneficial incentive

of equilibria, including “sunspot” runs equilibria as the Diamond-Dybvig (1983) liquidity provision model of deposit finance.

5 On information aggregation through market prices, see Grossman (1976), Hellwig (1980), Kyle (1989); on the usefulness of such information, see Allen (1993), Holmström and Tirole (1993).

6 On the distinction between the debt crises of the thirties and the eighties, see Eichengreen and Portes (1986). 
effects - even renegotiation ex post is infeasible. ${ }^{7}$ This is presumably a reason why adherents of "market discipline" extol the toughness by which markets - or rather the financiers with market instruments - avoid being drawn into cozy renegotiations with errant debtors. However the disadvantage is that, in the absence of subsequent renegotiations, it is impossible to adapt the contractual relation to changing circumstances, e.g., changes in international currency exchange rates, oil prices, and the like. Which of the two effects dominates depends on circumstances. However, it is interesting to note that the international loan renegotiations of the eighties did end up providing the international banks with substantial returns. ${ }^{8}$

Given these abstract theoretical considerations, I return to the question of what it is that financial "markets" do. The two simple characteristics that were mentioned above - namely a multiplicity of financiers and a prevalence of direct, rather than intermediated, finance - lend themselves to the view that market finance involves a regime where multiple investors fund a firm and collect information about a firm, and incentives for such information collection are provided by the fact that, through direct finance, they have a direct involvement. This view of market finance contrasts with a view of bank finance where a financial intermediary collects funds from final investors and, on his own account, invests these funds in various firms, each of which it monitors. The intermediary saves on information costs and is able to renegotiate contracts - indeed he is unable to commit not to renegotiate contracts.

These different views of market finance and bank finance involve different assumptions about information technologies. In one approach it is advantageous to have multiple sources of information; in the other this would be wasteful. Given the differences in assumptions, it seems fatuous to search for an unambiguous assessment as to which arrangement is likely to do better in the real world. This must depend on circumstances favouring one set of conditions or the other.

\section{Information Processing and "Discipline" under Market Finance}

Leaving the general comparative discussion, I now turn to the details of information collection, information aggregation, and incentive provision under market finance. The notion that prices aggregate information has been formalized by Grossman (1976). In his analysis, there are $n$ agents, each of whom receives a signal about a firm's returns. On the basis of his information, he buys or sells shares in the market. As the market price reflects the different traders' choices, so it will reflect their information, going up if on aggregate they want to acquire the stock and going down if on aggregate they want to divest it. In Grossman's model, remarkably, the price acts as a statistically efficient aggregator, i.e., once one knows the price, one knows as much about the stock return as if one knew the entire vector of individual signals.

7 In Diamond and Rajan (2001), this is the advantage of having multiple depositors providing finance to a bank.

8 On rates of return to international lending from the seventies to the nineties, see Klingen, Weder, Zettelmeyer (2002). 
This latter result is probably no more than a curiosum. Hellwig (1980) shows that the statistical efficiency of the aggregation of information through prices disappears once there is some "noise" in the market, i.e., a dependence of equilibrium prices on unknown variables other than the participants' information signals. Moreover, endogenizing people's decisions to acquire information or not, Verrecchia (1982), following Grossman and Stiglitz (1980) for the case of homogeneous information, has shown that, if the cost of acquiring information is positive, then the statistical properties of equilibrium prices are bounded away from efficiency, even if the level of "noise" in the market is small. If there is little "noise", there will just be very few people acquiring information, so that the effects of the information and of the "noise" on the equilibrium price will still be commensurate with each other, and the "noise" will be strong enough to contaminate the statistical properties of the relation between prices and information. The resulting equilibrium prices provide a noisy signal of aggregate information. This signal is useful to every individual in the market, but does not supersede the information that any one individual has on his own. The equilibrium informativeness of asset prices will depend on private incentives for information acquisition; it becomes larger if the costs of information acquisition decrease, e.g., because of a government subsidy.

Suppose we append a real investment story to the Grossman-Hellwig-Verrecchia model. For instance, suppose that the equilibrium real investment of the firm in question is given by an increasing function of its share price. Such a relation can easily be derived from a Tobin-q type of model based on the supply function of the investment goods industry. Then we find that positive information about the firm's prospects induces informed traders to buy the firm's shares; this generates a price increase. This price increase in turn motivates the firm to issue more shares and to buy additional investment goods. Alternatively, if information is negative, the firm is induced to reduce its real investment.

In this account, it is beneficial to have the information in question. By inducing the firm to have more real investment when the information about return prospects is good and the share price is high, and to have less real investment when the information about return prospects is bad, the system enables the economy to better adapt the allocation of scarce investment resources to the actual prospects that the different firms have. This enhances the efficiency of the use of these resources. Allen's (1993) view of the benefits of stock market finance for resource allocation is essentially based on this story.

Within the model, information acquisition choices are not actually efficient. If the response of the firm's real investment to the stock price is highly elastic, information acquisition is inefficiently low, and a subsidy to information acquisition, financed by a lump sum tax would raise aggregate surplus. There is a kind of free-rider problem in that each agent deciding upon the acquisition of information neglects the benefits he conveys to others when the impact of his portfolio choice on the stock price communicates some of his information to the rest of the economy, enabling them to adjust their portfolio positions as well and, most importantly, inducing the firm to adapt its real investment to the information. 
In contrast, if the response of the firm's real investment to the stock price is highly inelastic, information acquisition is inefficiently high, and a tax on information acquisition used to provide everybody with a lump sum subsidy would raise aggregate surplus. In this case, the firm's real investment hardly reacts to the information at all. There is however, a redistributive effect by which "liquidity traders", e.g., those people who want to liquidate stock for extraneous reasons that have nothing to do with the information, get less favourable terms from the market. The idea is that somebody has to make up for the costs of the information acquisition of informed traders. "Uninformed" conscious speculators will not do so because they appreciate the problem and can protect themselves, e.g., through the use of passive portfolio strategies. "Liquidity traders" are the only alternative. They suffer the redistributive externality, which is at work when information acquisition takes place, even though there is no or hardly any social benefit to be reaped from the information.

The proposition that information acquisition and the presence of people with private information harms those people who want to use the market for "real" purposes is very robust to changes in the institutional setting. This proposition identifies a key problem in the analysis of market microstructure. For example, if we consider a system based on market makers announcing buying and selling prices, the market makers must be afraid of having their offers taken up by an informed trader who causes the market maker to sell when the information is good and to buy when the information is bad. To reduce the impact of this problem, the market makers have a spread between buying and selling prices. The spread is higher, the more they are afraid of informed speculators; for infrequently traded stocks, e.g., in London, spreads on the order of $30 \%$ would not be unheard of. The spreads hurt liquidity traders, e.g., the people who want to sell in order to buy a house. As a seller, the liquidity trader receives a lower price; as a buyer, he pays a higher price than he would if market makers were sure that he was not acting on private information.

Informed speculation is thus a major problem for the viability of secondary financial markets. In some of the literature on insider trading, this observation is used to argue the extreme proposition that any securities trade on the basis of private information should be banned as insider trading. This extreme position underlies, e.g., the U.S. Supreme Court's position in the sixties, as well as the prosecution's stance (and some dissenting votes) in the cases of Chiarella and Dirks in the seventies and eighties. In these latter cases and others in the eighties, the U.S. Supreme Court has interpreted the ban on insider trading more narrowly, asking that there be some violation of fiduciary duty as well as a use of an information advantage (Dennert 1991). However, the notion that a ban on insider trading is a suitable measure to protect market functioning (as opposed to protecting fiduciary relationships) is based on the harm done by informed speculation to liquidity traders as they try to rely on the market.

In the model sketched above, these considerations of the harm that informed trading does to the functioning of secondary markets must be traded off against the social benefits of having real investment depend on the information. As discussed above, the comparison hinges upon whether real investment depends strongly or not so strongly on the information. Only if real investment choices are strongly affected by the information contained in stock prices will the social benefits 
outweigh the costs of having the functioning of markets disturbed. Allen's (1993) view, which was reported above, seems to presume that this is indeed the case.

Turning from the discussion of models to an assessment of such matters in reality, we need to ask how strongly the behaviour of the corporation depends on the price of its stock. In particular, how strong is the improvement-of-financing effect of the previous discussion in reality? What can be said about additional real effects of movements in stock prices?

Empirically, there is little doubt that asset prices do contain useful information. A particularly striking example is given by Roll's (1984) analysis of the futures market for frozen orange concentrates. According to Roll's findings, the prices for these contracts incorporated all the information that was contained in the forecasts of the U.S. weather service - and some additional information on top of that; the U.S. weather service could have improved the quality of its forecasts if it had taken account of the information contained in those prices. Similarly, Flannery's (1998) review of the empirical literature on information contained in bank share prices supports the policy recommendation that bank supervisors should try to exploit this information, using market assessments to shorten the lag before they intervene when an institution is in trouble.

Even so, I am highly sceptical about the practical relevance of the improvement-of-financing effect. The reason is not so much that some of the stock market finance we have seen in the late nineties has been misdirected. Rather, I am not convinced that the financing role of stock markets is anywhere commensurate with the overall activity in stocks that we observe. My scepticism is based on the observation that, in terms of net flows, in most economies, equity finance through new stock issues plays a relatively minor role (Mayer 1988, Hackethal and Schmidt 1998); and, moreover, for most firms, equity finance through new stock issues tends to be a once-in-a-lifetime event (Rajan and Zingales 1998). At the time when this event occurs, it may be of crucial importance, but this is quite a different story.

The strategies of repurchasing equity and simultaneously issuing new shares, which were pursued by American companies in the nineties, may lend more weight to the improvement-offinancing effect. Here, however, I would like to have a more precise account of how exactly the effect works for such strategies.

Given this scepticism about the improvement-of-finance effect, I turn to incentive provision as the second main candidate for explaining social benefits of stock prices containing information. Here I see three possible channels, outright incentive schemes, takeover threats, and boardroom rivalry. Outright incentive schemes involve stocks, stock options, and other devices that make managerial pay depend directly on the stock price. Up to 1990, such schemes played a surprisingly little role (Jensen and Murphy 1990); since then, they have become very prominent in some European countries as well as the United States. Incentive effects of takeover threats and boardroom rivalry depend on the possibility that a low share price may attract a potential raider or motivate a boardroom rival to stage a palace revolution. Either possibility may provide strong incentives to managers to prevent the stock price from falling. 
Behind the notion that market discipline has beneficial incentive effects, there is the idea that, in the absence of better information about managerial performance, reliance on the stock price can be useful because in any incentive problem it is always better to use additional information if one has it (Holmström 1979). On the basis of this idea, Holmström and Tirole (1993) have actually devised a model in which incentive schemes based on stock prices are useful - in spite of the existence of other sources of (partial) information about the company and in spite of the need to worry about speculators' incentives for information acquisition and the impact of informed speculation on the functioning of secondary markets.

However, there are two caveats. First, optimal incentive contracting makes incentive pay depend on those aspects of stock price movements that fall under the control of the managers in question. To the extent that a firm's prospects are determined by overall macroeconomic conditions and to the extent that the firm's share prices are driven by overall market movements, which have nothing to do with managerial behaviour, there is no reason to make managerial pay dependent on these price movements. Rewards that are paid when the overall market is going up have little to do with incentive provision. As discussed by Bebchuk and Fried (2004), outright incentive schemes that were implemented in the nineties did not make these distinctions and therefore had little to do with optimal incentive contracting.

Second, the theoretical models that have been studied have looked at effort as a single variable. In practice, managerial effort has many dimensions, e.g., effort to improve the firm's performance today and effort to improve the firm's prospects for the future. From the theory of multidimensional incentive provision (e.g., Holmström and Milgrom 1991), we know that in such situations, one must worry about the distribution of effort across the different dimensions. In particular, there is a danger that strong incentives in one dimension may induce an undersupply of effort in another dimension. This danger is particularly strong if the results of taking effort in one dimension can be measured relatively precisely and, in the other dimension, their measurement is subject to great uncertainty. In this case, the implementation of the optimal unidimensional incentive scheme for the first dimension leads to precisely the crowding out of effort in the second dimension that is to be feared (Holmström and Tirole 1993).

The stock price is a measure of the firm's overall return prospects, more precisely, of the riskadjusted expected present value of returns. As such it depends on current returns as a signal of overall prospects, as well as any additional information about what the firm's future prospects might be. In terms of the preceding discussion, one may therefore ask whether orienting managerial incentives on stock prices gives appropriate weights to different effort dimensions for performance today and for future prospects. If we think about cost cutting as a major element of managerial activity, we may ask whether outside investors would really be in a position to assess the relation between current cost savings and the associated diminution in output quantity or quality, especially if the latter concerns the future. Could it be that stock prices and shareholder value give too large a weight to the relatively hard information about current costs, relative to the relatively soft information about future prospects, thereby distorting incentives and inducing excessive cost cutting? Discussions about stock-based incentive schemes as well as shareholder 
value have perhaps paid too little attention to the problem of effort allocation when effort is multidimensional.

To conclude this discussion of information acquisition, information processing and "market discipline”, I note that none of the mechanisms effective today involve outright "discipline” in such that market participants get explicit powers to exert control. Incentive schemes are mutually agreed upon, and, moreover, they have little to do with control. They are introduced by corporate boards, usually at the initiative of incumbent managers; this is reflected in the observation that many of these schemes appear more as mechanisms for enrichment than as optimal contracting devices (Bebchuk and Fried 2004). Hostile takeovers have, by and large, ceased to be serious threats: The installation of anti-takeover defences in the years after 1989 has ensured that a takeover without managerial consent is hardly possible (Roe 1994, Useem 1993); managerial consent therefore is usually bought by large severance payments.

Finally, it will be easy for corporate executives to abandon the focus on shareholder value rhetoric in boardroom rivalry if boardroom fashions change once again. Its rise to prominence in the nineties poses a paradox, for, interestingly, the very corporate executives who have extolled shareholder value since the early nineties have also gone out of their way to reduce the scope for shareholder interference in their activities, introducing poison pill amendments into their corporate charters and the like (Useem 1993). The paradox is perhaps resolved by observing that the rise of shareholder value rhetoric coincided with the increase in the use of stock-price-related pay. This explanation, though, would be all the more reason for doubting the role of "stock market discipline” as a mechanism for control.

To understand this point, it is useful to go back to the Calomiris-Kahn model of deposit finance. In that model, control is exerted by each depositor individually as he asks for his money back; if enough depositors do this, the borrower goes bankrupt and the management of his assets is taken away from him. In contrast, the mechanisms of "market discipline” that are associated to stock price movements have no such immediate impact on the incumbent management's positioning of the firm. As discussed by Rochet and Vives (2004), the control mechanism associated with deposit may force inefficient liquidations. There seems to be a trade-off between the power of the disciplinary mechanism to really impose discipline and the efficiency of the ensuing resource allocation. The trade-off has to do with the greater subtlety of information aggregation, through prices rather than the demand deposit mechanism. The former provides more precise information without prejudging the ensuing allocation. The latter prejudges the ensuing allocation by imposing bankruptcy whenever a sufficient number of depositors want their money back. The relation between information aggregation mechanisms, on the one hand, and disciplinary intervention modes, on the other hand, would seem to be an important matter for future research. 


\section{Market Discipline and Corporate Governance in the Nineties}

The nineties, in particular the second half of the nineties, saw a remarkable shift towards market finance. Most prominent was of course the burst in outright equity finance that was supported by and in turn supporting the stock market boom. Whereas the economic expansion of the mid-tolate eighties had largely been funded by debt instruments, bonds in the United States and bank loans in Continental Europe, a large part of the expansion of the late nineties was financed by new equity, in Conttinental Europe as well as the United States. ${ }^{9}$ Even where loan finance was used, many of the issuing banks used securitization, in particular through credit derivatives, to shift the inherent risks from their own books into the books of third parties so that, in a certain sense, their role began to look like that of brokers or market makers rather than that of intermediaries who put their own money at risk.

Expansion of equity finance in the nineties was accompanied by an expansion of stock-pricerelated remuneration schemes for corporate executives, as well as an expanded use of the term "shareholder value" as the criterion by which to judge corporate managers in the financial press as well as in boardroom infighting. At first sight, therefore, it looks as though the developments of the nineties should be interpreted as a movement towards availing oneself of the benefits of market finance/direct finance and the associated incentive effects. Indeed, prior to the burst of the bubble in 2000, many observers interpreted the developments of the nineties in precisely these terms, arguing that, at least at this stage of economic development, a system based on market finance is superior (see, e.g., Rajan and Zingales 2003a, 2003b). The fact that this system facilitated the rise of Internet and biotech firms provides some substance to the assessment. After all, these are the sectors that capture the imagination as obvious carriers of technological progress.

Even the bubble and its fallout can be seen in a positive light. A decade earlier, the economic expansion of the late eighties in Continental Europe and Japan had largely been financed by bank loans to firms and real-estate investors. In the subsequent downturn, when loans turned sour, many banks were hard hit, and, in many countries, there were severe banking crises. Banking crises and banking problems in turn impaired the ability of these institutions to provide loans for new investments. With an absence of other institutions to take their place, there was a pronounced contraction in business investment, contributing further to a deepening of the recession. In some of the Scandinavian countries, for instance, the recession of the years $1991-1994$ rivalled the Great Depression in severity. In contrast, the fallout from the stock market implosion from 2000 to 2003 has been comparatively mild. The reason is that, apart from certain life insurance and pension institutions with insurance policies and pension plans involving defined benefits rather than defined contributions, the financial sector itself has not been much hit. ${ }^{10}$ In contrast to the early nineties, we have not seen a severe banking crisis during these years. The fallout from the burst of the bubble has not severely impaired the ability of financial systems to fund

9 Debt finance did become prominent in the very late stages of the expansion, around the year 2000, as telecommunications firms used bonds to continue financing their investments in network and in UMTS licences. 
new investment. To the extent that investment has lagged, this has been mainly because of a lack of demand, due to the presence of excess capacity in the aftermath of strong expansion in the late nineties.

At this point banking regulators might chime in and suggest that this beneficial development is precisely what they would have hoped for and what the various improvements in capital adequacy regulation of banks, in particular under the Basel II accord, are intended to achieve. Shift risks, in particular securitizable risks, out of the banks' books and into somebody else's, who presumably is better able to bear these risks, and who is perhaps also better able - or has better incentives - to monitor the ventures that are being financed. Economists worried about moral hazard in banking and finance would tend to agree, arguing that banks themselves are financed by deposits, i.e., debt-like instruments, and that the use of such instruments gives rise to excessive risk-taking as the borrower's gambles benefit him in the event of success and hurt the lenders in the event of failure, when the borrower goes bankrupt.

However, this sanguine view neglects a few observations which seem highly relevant for an appropriate descriptive assessment and a normative evaluation of what actually happened. In the first place, the fact that we have not had a major financial crisis induced by the stock market implosion does not mean that there have been no adverse effects. Adverse effects have merely been borne by parties other than banks, in particular by final consumers. As holders of stocks and mutual funds certificates or as participants of defined-contributions pensions plans, final consumers have been hard hit, with the consequence that many people will have to retire later and have to do with lower retirement incomes than they could have reckoned on. Insurance and pension institutions with contracts involving defined benefits have also been hit; the fact that these institutions' liabilities have long maturities has so far made it possible to smooth over many of their difficulties, but even so, there remains an open question for the future. ${ }^{11}$ At the very least, an argument is needed as to why it should preferable for private consumers and retirement institutions rather than banks to be bearing the consequences of the downturn.

Second, we need to take account of the fact that the overall development was accompanied by significant instances of wrongdoing, such as fraudulent reporting of business results or the mishandling of conflicts of interest by accounting firms and financial analysts, all of which occurred on a large scale, not just in a few exceptional cases. We also need to take account of the fact that the greater reliance on stock-price-related executive compensation was initiated by corporate management itself and that the details of this compensation had little to do with incentive provision in the sense of the theoretical models. Corporate managers were rewarded for stock price increases that were recognizably due to overall market developments or even macroeconomic developments that had nothing to do with their behaviours. Finally, we need to take account of the fact that resistance from corporate managers induced the political system in the United States

11 However, for someone recalling the US S\&L crisis in the eighties, the question arises whether the attempt to smooth over the effects - on these institutions - of the asset depreciation that has occurred may not give rise to a sort of gambling for resurrection that may end up being more detrimental than any effects of an immediate acknowledgement of the extent of the difficulties. 
to refrain from imposing appropriate accounting rules for certain forms of managerial compensation such as stock options, so profit reports were per se exaggerated, and there was no clear account of the cost of such compensation to the firm.

In the accounts of Rajan and Zingales (2003a, 2003b), the various instances of malfunctioning and malfeasance appear as unfortunate mishaps, as does the resistance of political systems to correcting them. These mishaps are seen as exceptions which should not lead us to question the ascendance of market finance. I disagree with this assessment. In my view, the instances of malfunctioning and malfeasance that we have seen exhibit some systematic features which, at the very least, raise doubts as to whether the ascendance of market finance in the nineties has anything to do with "market discipline”, let alone any of the theoretical models supporting the notion of market discipline.

As a first piece of analysis, consider the roles of analysts and accountants. The models of information processing through markets that I discussed above have no place for them; they are models of independent information gathering by final investors themselves. As discussed above, such information gathering by final investors is useful because it exploits the benefits of having multiple independent sources of information. In contrast, the analyst and the accountant would seem to be somewhat closer to the notion of delegated monitoring that is the basis of Diamond's (1984) theory of financial intermediation. The analyst specializes in information acquisition and communicates this information to investors. By having multiple investors rely on the information provided by an analyst, the system exploits the scale economies that are available through the avoidance of duplicate information collection.

The analogy between analysts gathering information on behalf of their clients and banks providing delegated monitoring à la Diamond (1984) raises the question of how a system involving analysts deals with the incentive problems arising from delegation. In Diamond (1984) this incentive problem is solved by having the bank provide financial intermediation as well as monitoring services, with debt finance of the bank ensuring that there is no incentive to misreport monitoring results or to underinvest in monitoring effort. In contrast, there is no such arrangement for stock market analysts. Given this lacuna, we should expect to see precisely what we saw in the late nineties, namely analysts not doing their homework or, worse, issuing reports that were at odds with the information they actually had if this served their other interests.

Adherents to the doctrine of market discipline would probably interject that analysts and accountants as well as investment bankers have their reputations to take care of, so proper incentives are being provided by the fact that they want to be successful in the future as well as the present. The argument presumes that the people concerned attach a lot of weight to the future relative to the present and, moreover, that stakes in the present are sufficiently small so that misbehaviour does not pay very much. On both accounts, I am sceptical. If current misbehaviour provides opportunities for earning a few million dollars, one may not care very much about losing one's business thereafter, provided one expects to keep the ill-gotten gains. We must also keep in mind that detection of misbehaviour may be quite difficult. After all, the investments in 
question are risky, so the mere fact that things have turned sour does not provide evidence that the advice had been bad, let alone fraudulent. In this context we may point to the results of empirical research on investment funds that indicates that a fund's ability to acquire new clients is most influenced by return realizations in the immediate past; the fact that high return realizations may reflect risk-taking rather than competence does not seem to be treated as a cause for concern; where such neglect may lead is shown by the unhappy fate of LTCM.

Another observation to be studied concerns the nature and governance of executive compensation schemes that were introduced. As mentioned before, these schemes had little to do with the incentive schemes studied in theoretical models (Bebchuk and Fried 2004): First, they provided remuneration for positive returns that had nothing to do with managerial behaviour - and could be recognized as such. Second, these schemes provided ample scope for mishandling the allocation of effort across different dimensions, e.g., through cutting clearly measurable costs today at the expense of unmeasurable, but nonetheless real prospects for tomorrow. To the extent that the effects of cost cutting were presented in terms of profit growth effects rather than level effects, the resulting incentive distortion was even larger. Third, these schemes provided significant management participation in upside risks, but, given the scope for the timing of the exercise of options, they provided little participation in downside risks.

As for the governance of these schemes, they had of course been introduced on the initiative of incumbent management itself, and they ended up providing a source of significant enrichment. Transparency about the costs of these schemes to the companies in question was impeded by inappropriate accounting rules, maintained by the U.S. Congress at the insistence of managerial lobbies. To the extent that incumbent managements were able to manipulate profit reports and to influence accountants, investment bankers, and analysts, incentive schemes may actually have generated more effort to influence stock prices through these channels than through an improvement in actual business activities.

In earlier work (Hellwig 2000, 2001), I had questioned the relevance of the traditional paradigm for studying corporate governance mainly as a matter of contractual relations and of institutions providing final investors with sufficient information and control to make it worth their while to provide companies with money. Given the empirical observation that corporate management in market-oriented and in bank-dominated systems alike enjoy a significant degree of autonomy, I had suggested that the mentioned similarity in governance structures across systems might be more important than the apparent differences. For bank-dominated systems, I pointed to the fact that, in a system where managements of large corporations are by and large autonomous, being subject to little outside control, there is no reason to expect banks to act as "delegated monitors" on behalf of final investors rather than as defendants of managerial interests, hoping to participate in the spoils by providing investment banking services at a time when corporate executives with cash cows in their back yards were looking for mergers and acquisitions. At the time, I formulated this argument as a comment on the role of main banks in a bank-dominated system. The experience of the nineties suggests that the very same argument is relevant for understanding the role of market institutions, accountants, analysts, and investment bankers, in a market-oriented 
system. This suspicion could make us pause and question our thinking about market discipline. Perhaps the market - just like any other institution - is just an instrument which corporate managers can use when it suits their purposes, as it so obviously did in the second half of the nineties. It certainly did not provide much discipline in that period.

However, we should recognize that the malfunctioning of institutions of the financial system that we have seen corresponds to what we should expect under financing structures involving significant elements of equity-like finance and the securitization of risks: Thus, a defined-contributions pension plan is subject to the standard agency problem of share finance; namely, the final investor bears the consequences of the fund managers' action. So in a trade-off between what contract theorists euphemistically call "private benefits", and the interests of the fund, the fund managers may have a tendency to pursue their own private benefits rather than the interests of the funds and its investors.

The increased incidence of this class of agency problems is a direct consequence of the move towards more equity finance and more securitized financial arrangements. Finding mechanisms for keeping these problems under control is essential to the viability of such arrangements in the future. However, we must keep in mind that although a system of supervision may seem foolproof by the standards of the day, if the stakes are high enough people will look for ways to get around them; and if enough people do so, they will find such ways. From this perspective, the instances of malfunctioning and malfeasance that we have seen should not have come as a surprise. Given the way the system evolved, they were bound to come. Moreover, if we think about modes of correction only in terms of the particular kinds of fraud and corruption that we have seen, the next round of problems is bound to come. We need to think about the problem as being endemic to a system in which the final investor foots the bill.

\section{Concluding Remark}

The analysis of this paper indicates that "market discipline" is no more a panacea for the problems of information, incentives, and control in finance than the "main bank relation". Different arrangements have different advantages and disadvantages in terms of how they align incentives between entrepreneurs and managers, financial institutions, and final investors. The experience of the past decade has shown the pitfalls of excessive confidence in a poorly regulated regime of "market discipline", just as the experience of the years 1980-1995 taught about the pitfalls of excessive intermediated loan finance inducing the risk of a credit crunch or a banking crisis. Examining these episodes in parallel provides a wholesome warning against excessive enthusiasm about either "system". However, as one thinks about the implications to be drawn, one should also bear in mind that in the actual developments in the nineties, the rise of market rhetoric - in academic as well as political discussion - seems to have merely provided the background for a development that was driven more by the people and institutions whom market discipline was supposed to be controlling than by the people and institutions for whom such control was supposed to be beneficial. 


\section{References}

Allen, F. (1993) Stock Markets and Resource Allocation, in: Mayer, C./ Vives, X. (eds.): Capital Markets and Financial Intermediation, Cambridge University Press, Cambridge, 81-116.

Allen, F. (2003), Discussion of 'Banks and Markets: The Changing Character of European Finance' by R. Rajan and L. Zingales, in: V. Gaspar, P. Hartmann, and O. Sleijpen (eds.), Second ECB Central Banking Conference: The transformation of the European Financial System, European Central Bank, Frankfurt, 169-172.

Basel Committee on Banking Supervision (2004), International Convergence of Capital Measurement and Capital Standards, A Revised Framework, Bank for International Settlements, Basel.

Bebchuk, L., and J. Fried (2004), Pay without Performance: The Unfulfilled Promise of Executive Compensation, Harvard University Press.

Calomiris, C.W. (1998), Reducing Moral Hazard: Introduci65

ng Market Signals into Banking Supervision, Economic Perspectives, US Information Agency.

Calomiris, C.W. (1999), Market-Based Banking Supervision, The Financial Regulator 4, 33-36.

Calomiris, C. W. and G. Gorton (1991), The Origins of Banking Panics, in: G. Hubbard (ed.), Financial Markets and Financial Crises, University of Chicago Press, Chicago, 109-173.

Calomiris, C. W., and C.M. Kahn (1991), The Role of Demandable Debt in Structuring Optimal Banking Arrangements, American Economic Review 81, 497-513.

Dennert, J. (1991), Insider Trading, Kyklos 44, 181-202.

Diamond, D. (1984), Financial Intermediation and Delegated Monitoring, Review of Economic Studies 51, 193-414.

Diamond, D. W., and P.H. Dybvig (1983), Bank Runs, Deposit Insurance, and Liquidity, Journal of Political Economy 91, 401-419.

Diamond, D.W., and R.G. Rajan (2001), Liquidity Risk, Liquidity Creation and Financial Fragility, Journal of Political Economy 109, 287-327.

Edwards, J., and K. Fischer (1994), Banks, Finance, and Investment in Germany, Cambridge University Press, Cambridge.

Eichengreen, B., and R. Portes (1986), Debt and Default in the 1930's: Causes and Consequences, European Economic Review 30. 
Flannery, M.J. (1998), Using Market Information in Prudential Bank Supervision: A Review of the U.S. Empirical Evidence, Journal of Money, Credit and Banking 30, 273-305.

Gerschenkron, A. (1962), Economic Backwardness in Historical Perspective, Harvard University Press.

Grossman, S. J. (1976), On the Efficiency of Competitive Stock Markets When Traders Have Diverse Information, Journal of Finance 31, 573-585.

Grossman, S.J., and O. D. Hart (1980), Takeover Bids, the Free-Rider Problem, and the Theory of the Corporation, Bell Journal of Economics 11, 42-64.

Grossman, S. J., and J.E. Stiglitz (1980), On the Impossibility of Informationally Efficient Markets, American Economic Review 70, 393-408.

Hackethal, A., and R. H. Schmidt (1999), Financing Patterns: Measurement Concepts and Empirical Results, Discussion Paper No. 33, Working Paper Series: Finance and Accounting, University of Frankfurt.

Hellwig, M.F. (1980), On the Aggregation of Information in Competitive Markets, Journal of Economic Theory 22, 477-498.

Hellwig, M.F. (1998): Banks, Markets, and the Allocation of Risks in an Economy, Journal of Institutional and Theoretical Economics 154, 328-345.

Hellwig, M.F. (2000), On the Economics and Politics of Corporate Finance and Corporate Control, in: Vives, X. (ed.): Corporate Governance, Cambridge University Press, Cambridge, 95-134.

Hellwig, M.F. (2001), Corporate Governance and the Financing of Investment for Structural Change, in: Deutsche Bundesbank (ed.), Investing Today for the World of Tomorrow • Studies on the Investment Process in Europe, Springer Verlag, Berlin, Heidelberg, New York 2001, 201-224.

Hellwig, M.F. (2003), Discussion of 'Banks and Markets: The Changing Character of European Finance' by R. Rajan and L. Zingales, in: V. Gaspar, P. Hartmann, and O. Sleijpen (eds.), Second ECB Central Banking Conference: The transformation of the European Financial System, European Central Bank, Frankfurt, 173-180.

Holmström, B. (1979), Moral Hazard and Observability, Bell Journal of Economics.

Holmström, B., and P..R. Milgrom (1991), Multitask Principal-Agent Analyses: Incentive Contracts, Asset Ownership, and Job Design, Journal of Law, Economics, and Organization 7 (suppl.), 24-52. 
Holmström, B., and J. Tirole (1993), Market Liquidity and Performance Monitoring, Journal of Political Economy 101, 678-709.

Hoshi, T., A. Kashyap, and D. Scharfstein (1990), The Role of Banks in Reducing Financial Distress in Japan, Journal of Financial Economics 27, 67-88.

Hoshi, T., A. Kashyap, and D. Scharfstein (1990), Corporate Structure, Liquidity and Investment, Quarterly Journal of Economics 106, 33-60.

Jensen, M. C., and K.J. Murphy (1990): Performance Pay and Top Management Incentives, Journal of Political Economy 98, 225-265.

Jensen, M. C., and R.S. Ruback (1983): The Market for Corporate Control: The Scientific Evidence, Journal of Financial Economics 11, 5-50.

Klingen, C., B. Weder, and J. Zettelmeyer (2004), How Private Creditors Fared in Emerging Debt Markets 1970 - 2000, Working Paper 04/13, International Monetary Fund, Washington.

Kyle, A.S. (1989), Informed Speculation with Imperfect Competition, Review of Economic Studies 56, 317-355.

La Porta, R., F. Lopez-de-Silanes, A. Shleifer, and R. Vishny (1997), Legal Determinants of External Finance, Journal of Finance 52, 1131-1150.

La Porta, R., F. Lopez-de-Silanes, A. Shleifer, and R. Vishny (1998), Law and Finance, Journal of Political Economy 106, 1113-1155.

Manne, A. (1965), Mergers and the Market for Corporate Control, Journal of Political Economy 73, $110-120$.

Mayer, C. (1988), New Issues in Corporate Finance, European Economic Review 32, 1167-1188.

Parigi, B.M., J.C. Rochet, and X. Vives (2004), The Lender of the Last Resort: A $21^{\text {st }}$ Century Approach, Working Paper 298, European Central Bank, Frankfurt.

Rajan, R.G., and L. Zingales (1998), Financial Dependence and Growth, American Economic Review 88, 559-586.

Rajan, R.G., and L. Zingales (2003a), The Great Reversals: The Politics of Financial Development in the Twentieth Century, Journal of Financial Intermediation 69, 5-50.

Rajan, R.G., and L. Zingales (2003b), Banks and Markets: The Changing Character of European Finance, in: V. Gaspar, P. Hartmann, and O. Sleijpen (eds.), Second ECB Central Banking Conference: The transformation of the European Financial System, European Central Bank, Frankfurt, 124-167. 
Rochet, J.C., and X. Vives (2004), Coordination Failure and the Lender of the Last Resort: Was Bagehot Right After All?, Journal of the European Economic Association 2, 1116-1147.

Roll, R.J. (1984), Orange Juice and Weather, American Economic Review 74, 861-880.

Shleifer, A., and R. Vishny (1997), A Survey of Corporate Governance, Journal of Finance 52, 737-783.

Stiglitz, J.E. (2002), Globalization and its Discontents, Norton.

Useem, M. (1993), Executive Defense: Shareholder Power and Corporate Reorganization, Harvard University Press, Cambridge, Massachusetts.

Verrecchia, R.E. (1982), Information Acquisition in a Noisy Rational Expectations Economy, Econometrica 50, 1415-1430. 